Jurnal Indonesia Sosial Teknologi:p-ISSN: 2723 - 6609

e-ISSN : 2745-5254

Vol. 2, No.12 Desember 2021

\title{
ANALISIS PENYEBAB YANG MEMPENGARUHI TERJADINYA KETERLAMBATAN PENGADAAN BARANG PADA PT. PETROJAYA BORAL PLASTERBOARD GRESIK
}

\author{
In'amy Fawwaz ${ }^{1}$, Abdurrahman Faris Indriya Himawan ${ }^{2}$ \\ Program Studi Manajemen, Fakultas Ekonomi dan Bisnis, Universitas Muhammadiyah \\ Gresik \\ Email : inamyfawwaz@gmail.com ${ }^{1}$, faris@umg.ac.id ${ }^{2}$
}

\begin{abstract}
Abstrak
Penting adanya proses pengadaan barang untuk mempertahankan kelangsungan hidup perusahaan terutama dalam industri manufaktur. PT. Petrojaya Boral Plasterboard Gresik merupakan perusahaan yang bergerak di bidang manufaktur yang mana untuk proses produksi, sangat penting dalam memperhatikan proses pengadaan. Terjadinya keterlambatan dalam proses pengadaan dapat menyebabkan terganggunya kegiatan operasional perusahaan. Penelitian ini dilakukan bertujuan untuk mengetahui dan menganalisis penyebab keterlambatan pengadaan barang. Jenis penelitian yang digunakan oleh peneliti adalah deskriptif kualitatif dengan subjek penelitian adalah karyawan yang berhubungan langsung dengan proses pengadaan barang di PT. Petrojaya Boral Plasterboard Gresik. Hasil penelitian menunjukan bahwa faktor-faktor penyebab masalah keterlambatan pengadaan barang diantaranya adalah (1) Barang inden,(2) Pemberlakuan pembatasan kegiatan masyarakat (PPKM), (3) Menunggu jadwal pengiriman, (4) Banyak karyawan isolasi mandiri, (5) Barang fabrikasi, (6) Stock kosong, (7) Progress project, (8) Barang spesifik, (9) Tukar barang karena tidak sesuai, dan (10) Menunggu design. Bagian pengadaan perlu mengatasi permasalahan tersebut dengan membuat strategi yang baik dalam menjaga ketersediaan stock barang untuk proses produksi dalam periode tertentu dan juga meningkatkan komunikasi antara bagian pengadaan dan supplier agar purchase order yang diterbitkan dapat terkoordinasi dengan baik.
\end{abstract}

Kata kunci: Pengadaan Barang, Pesanan Pembelian, Penyebab Keterlambatan

\section{Abstract}

The importance of the procurement process of goods to maintain the survival of the company, especially in the manufacturing industry. PT. Petrojaya Boral Plasterboard Gresik is a company engaged in manufacturing which for the production process, is very important in paying attention to the procurement process. The occurrence of delays in the procurement process can cause disruption of the company's operational activities. This research is conducted to find out and analyze the causes of delays in the procurement of goods. This study used the descriptive qualitative method. The subject of this research was the employees that has contributed directly with procurement in PT. Petrojaya Boral Plasterboard Gresik. The results showed that the main causative factors for delayed procurement problems included (1) Indented goods, (2) The enactment of restrictions on 
Analisis Penyebab yang Mempengaruhi Terjadinya Keterlambatan Pengadaan Barang Pada PT. Petrojaya Boral Plasterboard Gresik

community activities (PPKM), (3) Waiting for delivery schedules, (4) Many employees self-isolation, (5) Fabrication goods, (6) Empty stock, (7) Progress project, (8) Specific goods, (9) Exchange of goods because they are not appropriate, and (10) Waiting for design. The procurement department needs to overcome these problems by making a good strategy in maintaining the availability of stock of goods for the production process in a certain period and improving communication between the procurement and supplier sections so that purchase orders issued can be coordinated properly.

Keywords: Procurement, Purchase Order, Cause of delay

\section{Pendahuluan}

Seiring pertumbuhan dunia bisnis, banyaknya perusahaan baru yang hadir sehingga dapat menjadi penyebab adanya banyak persaingan di dunia industri. Hal tersebut menuntut perusahaan memiliki kebijakan yang tepat agar perusahaan dapat bertahan di dunia persaingan. Dengan semakin ketatnya persaingan, dibutuhkan pengendalian, perhatian dan keterampilan dari manajemen (Sutarman \& Atif, 2017).

Procurement atau pengadaan adalah salah satu komponen utama dari Supply Chain Management yang memiliki tugas mengadakan atau menyediakan input yang berupa barang atau jasa yang diperlukan dalam kegiatan produksi atau kegiatan lain dari sebuah perusahaan. Dalam sebuah perusahaan, bagian pengadaan akan menyediakan barang-barang yang dibutuhkan (Probowati, 2011). Barang-barang tersebut dapat diklasifikasikan secara umum menjadi bahan baku dan komponen untuk kebutuhan produksi, capital equipment (mesin dan peralatan jangka panjang), alat-alat yang menunjang barang lainnya atau biasa dinamakan Maintenance, Repair, dan Operating Supplies (MRO). Selain itu, bagian ini memiliki tugas seperti menyediakan jasa transportasi dan pergudangan, jasa konsultasi, dan sebagainya (Pujawan, 2017).

PT. Petrojaya Boral Plasterboard Gresik adalah salah satu perusahaan manufaktur penghasil papan gipsum di Indonesia. Perusahaan ini didirikan di Gresik dan mulai berproduksi pada tahun 1994. PT. Perojaya Boral Plasterboard mempunyai beberapa proses dalam menjalankan pengadaan barang. Proses tersebut dapat secara tidak langsung menjadi langkah awal untuk menjamin kelancaran kelangsungan operasional perusahaan (Jusriadi \& Ario, 2020). Proses tersebut diantaranya adalah Proses Purchase Order yang sebagai awal proses pengadaan barang. Purchase order adalah bentuk kontrak atau perjanjian antara pengguna dengan pemasok barang dalam melaksanakan kegiatan pengadaan barang (Siahaya, 2013). Proses Monitoring sebagai proses lanjutan dari proses purchase order, dan diakhiri Proses Receiving. Selain memperhatikan proses purchase order, perusahaan sangat memperhatikan proses monitoring.

Menurut (Sihotang, 2019) Proses Monitoring merupakan proses pemantauan perjalanan barang dari mulai purchase order yang telah di approval hingga barang yang dipesan sampai pada waktu dan tempat yang disepakati kemudian dilanjutkan proses penerimaan barang, sehingga proses monitoring diharapkan dapat dilaksanakan dengan 
baik supaya barang yang telah dipesan tepat kualitas, tepat jumlah, tepat harga, tepat tempat dan yang terpenting adalah tepat waktu karena berhubungan langsung dengan lead time.

Menurut (Indriani \& Slamet, 2015) Lead Time adalah jangka waktu yang dibutuhkan sejak mulai dilakukan pemesanan sampai dengan datangnya bahan baku yang sudah dipesan. Lead time menjadi salah satu hal yang penting dan perlu diperhatikan khusus dalam menjalankan berbagai proses yang dilakukan untuk mencapai keberhasilan pada proses pengadaan terutama dalam mempengaruhi kelangsungan operasional perusahaan (Kamaluddin \& Patta Rapanna, 2017). Apabila dalam proses pengadaan tidak mengatur lead time dengan baik, maka barang yang sudah dipesan tidak datang sesuai dengn jadwal. Hal ini menyebabkan proses manufaktur terhambat dan perusahaan dapat mengalami kerugian. Selain itu, apabila sering terjadi keterlambatan dalam pembelian, maka harus dibutuhkan persediaan pengaman yang cukup besar, sedangkan sebaliknya apabila pembelian sesuai dengan jadwal, maka tidak dibutuhkan persediaan pengaman yang besar (Prayunantyo \& Supriono, 2017).

Penjualan barang yang tidak hanya dalam negeri namun juga di luar negeri, sehingga dalam mempertahankan kualitas barang, perusahaan harus mampu menjamin kelancaran proses manufaktur dimana proses tersebut sangat dipengaruhi oleh ketersediaan barang (Fuad, 2006). Untuk menjamin ketersediaan dan mempertahankan kualitas barang tersebut, bagian pengadaan dituntut untuk dapat menghasilkan keunggulan dari segi waktu. Keunggulan dari segi waktu dapat dilakukan bagian pengadaan yaitu dengan memilih supplier yang mempunyai kemampuan untuk mengirim barang dalam waktu yang lebih pendek namun tanpa harus meningkatkan harga dan mengorbankan kualitas (Alif, 2020). Ketepatan dan kecepatan waktu pengiriman dari supplier tidak hanya memugkinkan perusahaan untuk memproduksi dan mengirim produk ke customer secara tepat waktu namun juga dapat mengurangi tingkat persediaan bahan baku dan komponen yang harus disimpan maka akan dapat berakibat pada penghematan biaya.

Pentingnya analisis ini dilakukan agar dapat mengetahui penyebab yang mempengaruhi terjadinya keterlambatan pengadaan barang dan solusi yang dibutuhkan untuk mengatasi masalah terjadinya keterlambatan pengadaan barang pada PT. Petrojaya Boral Plasterboard Gresik.

\section{Metode Penelitian}

A. Lokasi Penelitian

Penelitian ini bertujuan untuk mendapatkan gambaran dan informasi yang lengkap, jelas, serta memungkinkan untuk melakukan observasi bagi peneliti. Oleh sebab itu peneliti menetapkan lokasi penelitian di PT. Petrojaya Boral Plasterboard yang beralamat di Jl. Prof. Dr. M. Yamin Desa Roomo Kecamatan Manyar Kabupaten Gresik 61151.

B. Metode Pengumpulan Data 
Analisis Penyebab yang Mempengaruhi Terjadinya Keterlambatan Pengadaan Barang Pada PT. Petrojaya Boral Plasterboard Gresik

Teknik pengumpulan data merupakan suatu langkah yang dinilai strategis dalam penelitian (David, 2011), karena mempunyai tujuan yang utama dari penelitian adalah mendapatkan data. Peneliti terjun langsung pada objek penelitian agar bisa mendapatkan data yang valid, dalam penelitian ini peneliti menggunakan metode antara lain :

1. Metode Wawancara (Interview)

Menurut (Sugiyono, 2017) wawancara merupakan pertemuan dua orang untuk saling bertukar informasi melalui tanya jawab sehingga dapat dikonstruksikan makna pada suatu topik tertentu. Dengan adanya wawancara maka peneliti dapat mengetahui halhal yang lebih mendalam terkait partisipan dalam menginterpretasikan situasi fenomena dan situasi yang terjadi dimana hal tersebut tidak dapat ditemukan melalui observasi. Wawancara pada penelitian ini dilakukan kepada karyawan yang bekerja pada proses bagian pengadaan.

2. Metode Observasi

Menurut (Sugiyono, 2017) Observasi adalah dasar semua ilmu pengetahuan, melalui observasi peneliti belajar tentang perilaku, dan makna dari perilaku tersebut. Metode ini digunakan untuk mengamati secara langsung peristiwa/fenomena yang menjadi fokus penelitian. Pada penelitian ini, peneliti terlibat dengan kegiatan sehari-hari orang yang sedang diamati sebagai sumber data penelitian atau yang disebut dengan observasi partisipatif.

\section{Metode Dokumentasi}

Menurut (Sugiyono, 2017) Dokumen merupakan catatan peristiwa yang sudah berlalu baik berupa tulisan, gambar atau karya-karya monumental dari seseorang. Studi dokumen merupakan pelengkap dari penggunaan metode observasi dan wawancara dalam penelitian kualitatif. Pada penelitian ini peneliti lebih banyak menggunakan dokumen yang berbentuk tulisan seperti buku panduan prosedur pengadaan barang, lembar purchase requisition, lembar purchase order, dan goods received notes.

C. Metode Analisis Data

Metode analisis data yang digunakan dalam penelitian ini adalah metode analisis deskriptif kualitatif yakni metode penelitian yang menjelaskan kondisi yang terjadi sebenarnya secara konkrit serta mengklasifikasikan hasil penelitian. Menurut (Sugiyono, 2017) menyatakan bahwa metode penelitian kualitatif adalah metode penelitian yang berdasarkan pada filsafat postpositivisme yang digunakan untuk melakukan penelitian pada kondisi objek yang alamiah (sebagai lawannya adalah eksperimen) dimana peneliti adalah sebagai instrumen murni) teknik pengumpulan data dilaksanakan secara triangulasi (gabungan wawancara, observasi, dan dokumentasi), analisis data bersifat induktif atau kualitatif, dan hasil penelitian kualitatif lebih menekankan makna daripada generalisasi. 


\section{Hasil dan Pembahasan}

Pembelian barang adalah hal yang sangat penting bagi perusahaan manufaktur seperti PT. Petrojaya Boral Plasterboard Gresik dalam memenuhi kebutuhan operasional perusahaan. Dengan terpenuhinya barang yang dibutuhkan, proses produksi pun dapat berjalan dengan lancar dan permintaan produk yang telah dipesan oleh konsumen dapat terkirim sesuai jadwal. (Aryadi \& Wahyuni, 2019) Berdasarkan data yang didapat dari hasil penelitian yang telah dilaksanakan oleh peneliti di PT. Petrojaya Boral Plasterboard Gresik, maka prosedur pembelian barang dapat dilihat pada tabel dibawah ini :

Tabel 1 Proses Pembelian Barang PT. Petrojaya Boral Plasterboard Gresik

\begin{tabular}{|c|c|c|}
\hline No & Proses & Keterangan \\
\hline 1 & $\begin{array}{l}\text { Menerima } \\
\text { requisition }\end{array}$ & $\begin{array}{l}\text { Plant purchaser terlebih dahulu menerima surat } \\
\text { daftar permintaan barang yang dibutuhkan oleh } \\
\text { user sebelum dilakukannya proses pembelian } \\
\text { barang. }\end{array}$ \\
\hline 2 & $\begin{array}{l}\text { Melakukan } \\
\text { supplier }\end{array}$ & $\begin{array}{l}\text { Proses ini dilakukan sesuai kebutuhan dari } \\
\text { perusahaan untuk memenuhi stok barang yang } \\
\text { dibutuhkan. }\end{array}$ \\
\hline 3 & $\begin{array}{l}\text { Pengajuan permintaan } \\
\text { penawaran harga }\end{array}$ & $\begin{array}{l}\text { Plant purchaser akan terlebih dahulu membuat } \\
\text { surat permintaan penawaran harga barang ke } \\
\text { supplier sebelum terjadinya proses pembuatan } \\
\text { purchase order. }\end{array}$ \\
\hline 4 & $\begin{array}{l}\text { Seleksi supplier berdasarkan } \\
\text { kualitas, harga, dan jadwal } \\
\text { pengiriman. }\end{array}$ & $\begin{array}{l}\text { Proses ini terjadi pada saat pihak plant purchaser } \\
\text { menerima surat penawaran harga yang telah } \\
\text { diberikan oleh supplier dan plant purchaser } \\
\text { melakukan seleksi supplier yang akan dipilih } \\
\text { berdasarkan kualitas barang, harga barang, dan } \\
\text { jadwal pengiriman barang. }\end{array}$ \\
\hline 5 & Proses Approval & $\begin{array}{l}\text { Setelah menentukan supplier yang dipilih maka } \\
\text { proses yang selanjutnya adalah meminta approval } \\
\text { melalui sistem perusahaan. }\end{array}$ \\
\hline 6 & Penerbitan purchase order & $\begin{array}{l}\text { Setelah melaksanakan beberapa tahap yang telah } \\
\text { dilakukan oleh plant purchaser, maka akan } \\
\text { diterbitkan purchase order untuk supplier yang } \\
\text { telah lolos seleksi }\end{array}$ \\
\hline 7 & Monitoring status order & $\begin{array}{l}\text { Setelah purchase order diterbitkan ke supplier, } \\
\text { maka plant purchaser melakukan pemantauan } \\
\text { status pengiriman barang. }\end{array}$ \\
\hline
\end{tabular}

Sumber : PT. Petrojaya Boral Plasterboard 
Analisis Penyebab yang Mempengaruhi Terjadinya Keterlambatan Pengadaan Barang Pada PT. Petrojaya Boral Plasterboard Gresik

Berikut adalah alur proses pengadaan barang pada PT. Petrojaya Boral Plasterboard Gresik :

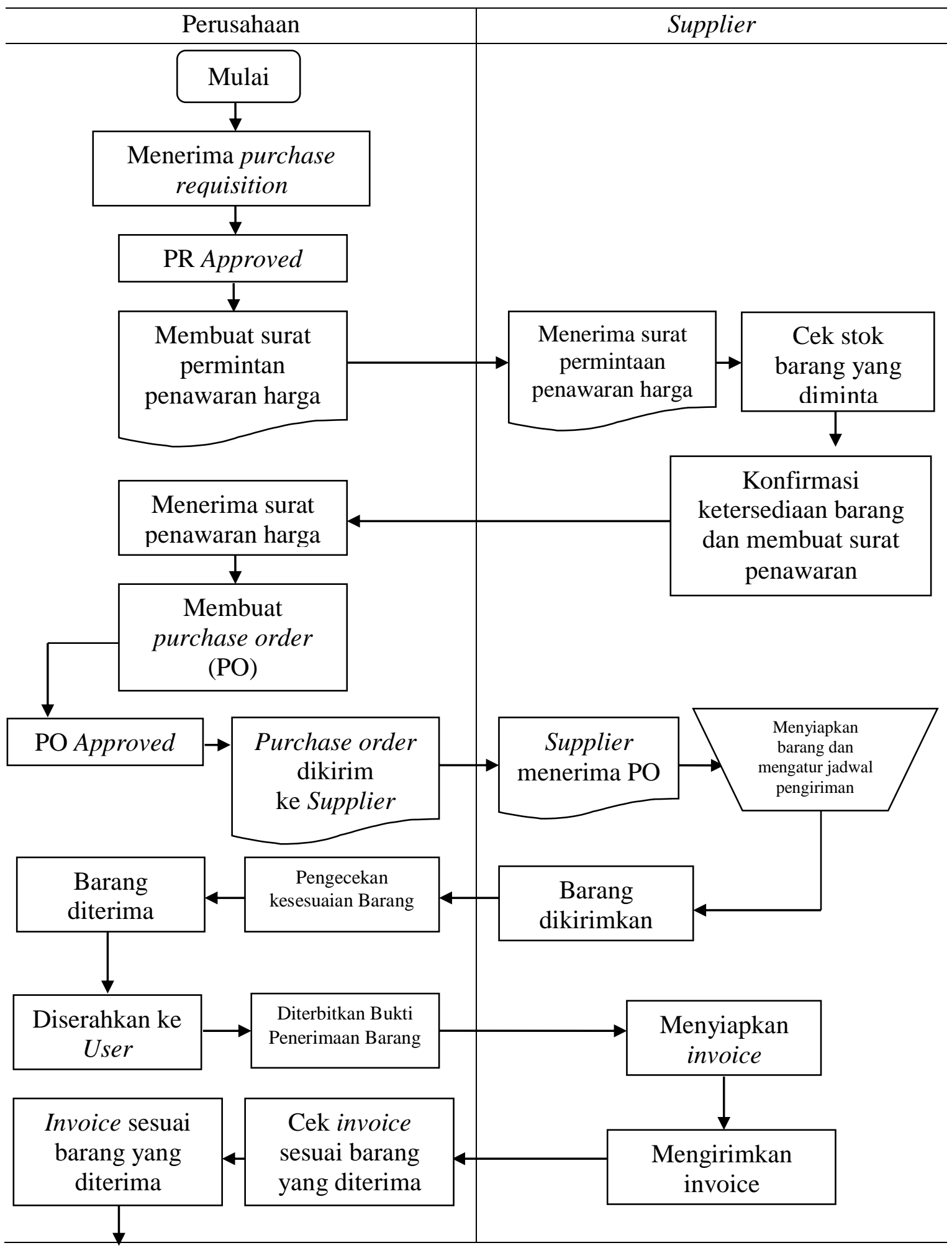

Jurnal Indonesia SosialTeknologi, Vol. 2, No.12, Desembe Selesai 
In'amy Fawwaz, Abdurrahman Faris Indriya Himawan

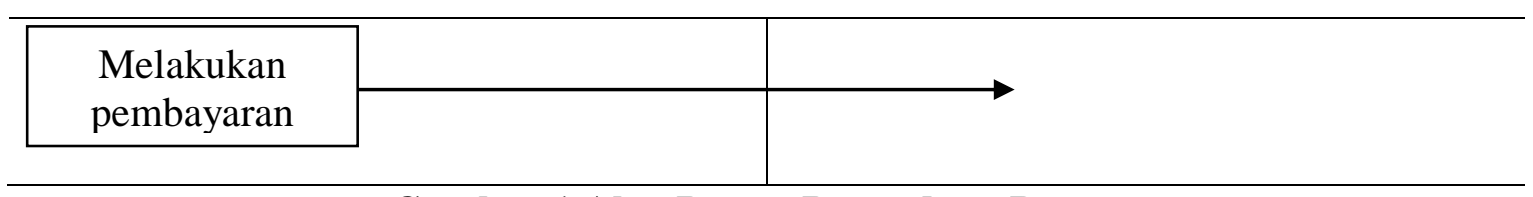

\section{Gambar 1 Alur Proses Pengadaan Barang}

Dari analisis data yang telah dilakukan terdapat kendala yang dihadapi oleh bagian pengadaan dalam melakukan proses pengadaan barang yaitu terjadinya keterlambatan pengadaan barang pada PT. Petrojaya Boral Plasterboard Gresik. Berikut adalah data jumlah purchase order yang dipesan selama bulan Januari 2021 sampai dengan bulan Oktober 2021 dibedakan menjadi dua jenis pesanan yaitu jumlah nomor purchase order yang datang sebelum batas waktu penyerahan dan jumlah nomor purchase order yang datang setelah batas waktu penyerahan.

Tabel 2 Jumlah Purchase Order Bulan Januari - Oktober 2021

\begin{tabular}{ccccccc}
\hline \multirow{2}{*}{ No } & Bulan & $\begin{array}{c}\text { Total } \\
\text { Purchase } \\
\text { Order }\end{array}$ & \multicolumn{2}{c}{$\begin{array}{c}\text { Sebelum Batas Waktu } \\
\text { Penyerahan }\end{array}$} & \multicolumn{2}{c}{$\begin{array}{c}\text { Setelah Batas Waktu } \\
\text { Penyerahan }\end{array}$} \\
\cline { 4 - 7 } & & 162 & 143 & $88,27 \%$ & 19 & $11,73 \%$ \\
\hline 1 & Januari & 158 & 147 & $93,04 \%$ & 11 & $6,96 \%$ \\
\hline 2 & Februari & 150 & 139 & $92,67 \%$ & 11 & $7,33 \%$ \\
\hline 3 & Maret & 201 & 188 & $93,53 \%$ & 13 & $6,47 \%$ \\
\hline 4 & April & 121 & 109 & $90,08 \%$ & 12 & $9,92 \%$ \\
\hline 5 & Mei & 137 & 126 & $91,97 \%$ & 11 & $8,03 \%$ \\
\hline 6 & Juni & 139 & 122 & $87,77 \%$ & 17 & $12,23 \%$ \\
\hline 7 & Juli & 147 & 138 & $93,88 \%$ & 9 & $6,12 \%$ \\
\hline 8 & Agustus & 160 & 149 & $93,13 \%$ & 11 & $6,88 \%$ \\
\hline 9 & September & 163 & 157 & $96,32 \%$ & 6 & $3,68 \%$ \\
\hline 10 & Oktober & $\mathbf{1 5 3 8}$ & $\mathbf{1 4 1 8}$ & & $\mathbf{1 2 0}$ & \\
\hline & Total & Jumlah PO & Persentase & & Persentase \\
\hline
\end{tabular}

Sumber : PT. Petrojaya Boral Plasterboard Gresik (2021) 
Analisis Penyebab yang Mempengaruhi Terjadinya Keterlambatan Pengadaan Barang Pada PT. Petrojaya Boral Plasterboard Gresik

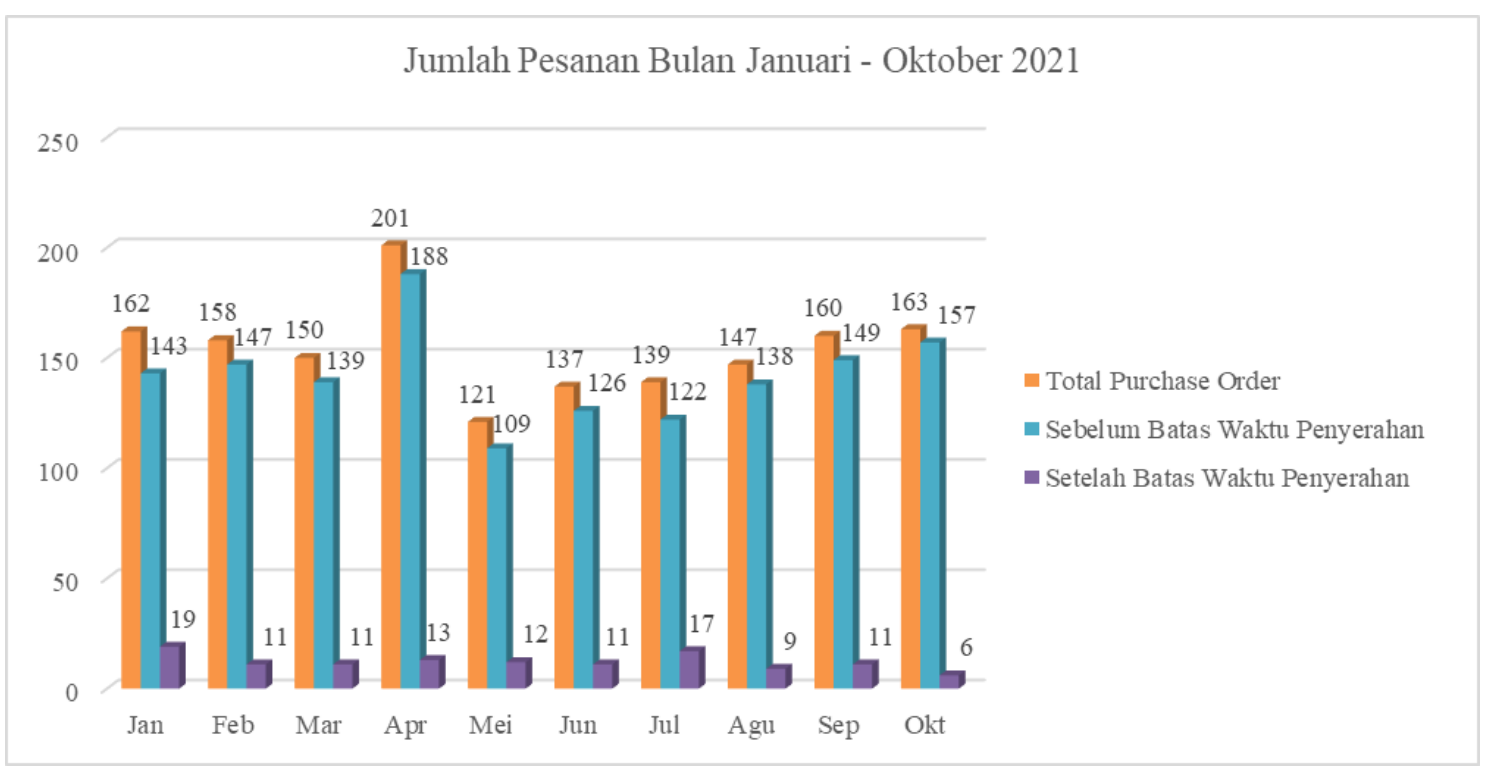

Gambar 2 Jumlah Pesanan Barang Bulan Januari - Oktober 2021

Purchase order selama bulan Januari 2021 sampai dengan bulan Oktober 2021 terdapat perbedaan jumlah nomor purchase order datang sebelum batas waktu penyerahan dan jumlah nomor purchase order yang datang setelah batas waktu penyerahan yang tercantum pada form purchase order. Pada bulan Januari 2021 terdapat sebanyak 162 nomor purchase order yang diterbitkan kepada supplier, sebanyak 143 nomor purchase order atau sebesar 88,27\% barang telah dikirimkan sebelum batas waktu penyerahan sedangkan terdapat 19 nomor purchase order atau sebesar $11,73 \%$ barang dikirimkan setelah batas waktu penyerahan.

Terdapat 1.418 nomor purchase order dikirimkan oleh supplier dalam waktu yang tepat berdasarkan kesepakatan dan sesuai dengan batas waktu penyerahan barang yang tercantum dalam form purchase order. Namun dalam tabel tersebut juga menjelaskan terdapat 120 nomor purchase order yang dikirim setelah batas waktu penyerahan sehingga terjadi keterlambatan dalam pengadaan barang. Meskipun jumlah nomor purchase order yang datang melebihi batas waktu penyerahan lebih dibawah jumlah nomor purchase order yang dikirimkan sebelum batas waktu penyerahan, namun apabila hal ini sering terjadi secara berkelanjutan maka dapat mempengaruhi kelancaran proses manufaktur.

Beberapa masalah yang terjadi dalam proses pengadaan barang untuk kelancaran proses manufaktur sehingga perlu melakukan analisa terhadap penyebab terjadinya keterlambatan penyerahan barang oleh supplier. Analisis penyebab keterlambatan dibantu dengan menggunakan metode Diagram Fishbone, pada tahap pembuatan diagram fishbone dari setiap keterlambaan yang diteliti didasari atas hasil wawancara penulis dengan karyawan bagian pengadaan, dari hasil wawancara yang dilakukan penulis maka setiap fakor penyebab dari setiap jenis keterlambatan yang terjadi pada pengadaan barang yang kemudian dapat digambarkan dalam bentuk diagram fishbone berikut ini : 


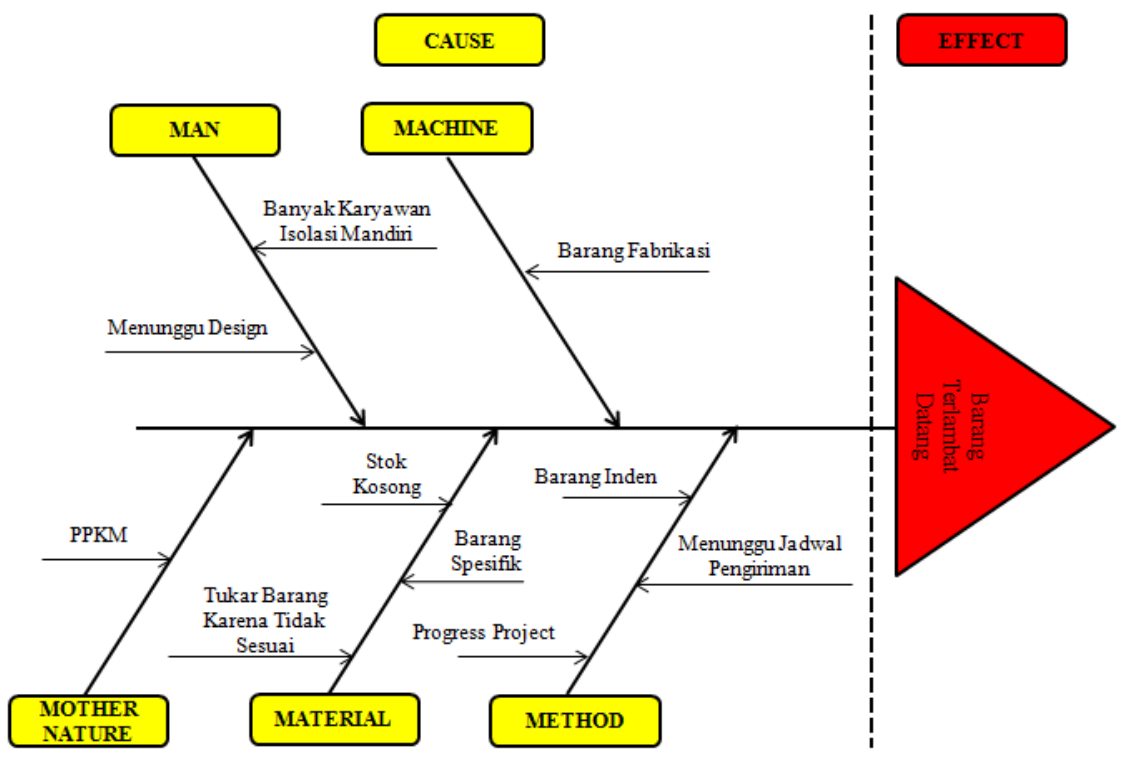

\section{Gambar 3 Diagram Fishbone Penyebab Keterlambatan Pengadaan Barang}

Berikut diperoleh data analisa penyebab keterlambatan penyerahan barang oleh supplier periode Januari 2021 sampai dengan Oktober 2021.

Tabel 3 Penyebab Keterlambatan Bulan Januari - Oktober 2021

\begin{tabular}{llcc}
\hline No & Penyebab Keterlambatan & $\begin{array}{c}\text { Jumlah PO } \\
\text { yang } \\
\text { Terlambat }\end{array}$ & Persentase \\
\hline 1 & Barang Inden & 36 & $30,00 \%$ \\
\hline 2 & Pemberlakuan Pembatasan Kegiatan Masyarakat & 19 & $15,83 \%$ \\
\hline 3 & Menunggu Jadwal Pengiriman & 19 & $15,83 \%$ \\
\hline 4 & Banyak Karyawan Isolasi Mandiri & 13 & $10,83 \%$ \\
\hline 5 & Barang Fabrikasi & 10 & $8,33 \%$ \\
\hline 6 & Stock Kosong & 9 & $7,50 \%$ \\
\hline 7 & Progress Project & 8 & $6,67 \%$ \\
\hline 8 & Barang Spesifik & 3 & $2,50 \%$ \\
\hline 9 & Tukar Barang Karena Tidak Sesuai & 2 & $1,67 \%$ \\
\hline 10 & Menunggu Design & 1 & $0,83 \%$ \\
\hline & & 120 & $100 \%$ \\
\hline
\end{tabular}

Berdasarkan tabel di atas, menjelaskan sebanyak 10 faktor yang menjadi penyebabnya keterlambatan pengadaan barang diantaranya penyebab masalah yang paling banyak frekuensinya adalah sebanyak 36 dari 120 nomor purchase order atau $30 \%$ keterlambatan penyerahan barang disebabkan karena barang tersebut adalah barang inden, untuk itu bagian pengadaan perlu mengambil suatu tindakan perbaikan atau kebijakan yaitu meningkatkan kerjasama dengan supplier untuk memperhatikan 
Analisis Penyebab yang Mempengaruhi Terjadinya Keterlambatan Pengadaan Barang Pada PT. Petrojaya Boral Plasterboard Gresik

kejelasan pengadaan barang atau pengiriman barang sesuai dengan jadwal yang sudah ditentukan. Bagian pengadaan perlu memperhatikan saldo minimum stock persediaan barang baik itu melalui sistem perusahaan dan ataupun secara fisik. Selain itu, bagian planner perlu membuat forecast atau rencana proses produksi dalam satu periode dan menyerahkan ke bagian pengadaan. Agar bagian pengadaan dapat memprediksi kebutuhan barang atau bahan yang diperlukan untuk proses produksi. Hal ini dapat mengantisipasi terjadinya kehabisan stock barang yang diperlukan, meskipun sifat barang ketegori ready stock maupun inden.

Faktor kedua penyebab keterlambatan pengadaan barang adalah Pemberlakuan Pembatasan Kegiatan Masyarakat (PPKM) yaitu sebanyak 19 dari 120 nomor purchase order atau sebesar $15,83 \%$. Kebijakan pemerintah dalam mengatasi situasi pandemi Covid 19 yang menyebabkan adanya pembatasan mobilisasi kendaraan baik darat, laut maupun udara, sehingga proses pengiriman barang membutuhkan waktu melebihi proses wajar. Proses pengiriman yang terlambat sangat berdampak terhadap waktu penyerahan barang. Hal ini tidak dapat dihindari oleh semua orang terutama pelaku usaha, karena situasi yang belum bisa diprediksi oleh perusahaan terutama dalam pemenuhan barang proses manufaktur. Namun untuk periode berikutnya, bagian pengadaan perlu mengatasi masalah tersebut dengan meminta bagian produksi membuat rencana proses produksi beberapa periode kedepan agar bagian pengadaan dapat menjaga stock barang dan apabila sudah mencapai saldo minimum, bagian pengadaan menerbitkan purchase order barang kepada supplier dengan lead time yang baik dan sesuai dengan yang diharapkan.

Faktor ketiga penyebab keterlambatan pengadaan barang adalah menunggu jadwal pengiriman yaitu sebanyak 19 dari 120 nomor purchase order atau sebesar $15,83 \%$. Supplier mempunyai jadwal pengiriman yang berbeda hari pada setiap area pengiriman sehingga terkadang barang yang seharusnya dikirimkan sesuai pada jadwal yang tertulis pada form purchase order namun supplier baru dapat mengirimkan ke perusahaan sesuai jadwal yang dimiliki mereka yang bergantung pada hari pengiriman pada setiap area. Selain itu dari perusahaan juga meminta pengiriman barang pada jadwal tertentu sesuai kebutuhan operasional produksi yang terkadang lebih dari tanggal yang tertulis pada form purchase order. Dalam hal ini bagian pengadaan sebaiknya sebelum menerbitkan purchase order terlebih dahulu mengkonfirmasi kepada supplier berkenaan jadwal pengiriman mereka sehingga bagian pengadaan dapat menjadwalkan pengiriman barang lebih awal.

Faktor keempat penyebab keterlambatan pengadaan barang adalah banyak karyawan isolasi mandiri yaitu sebanyak 13 dari 120 nomor purchase order atau sebesar 10,83\%. Banyaknya karyawan dari supplier yang sedang isolasi mandiri karena terinfeksi Covid19 sehingga supplier meminta keringanan dari batas tanggal penyerahan tersebut. Dalam hal ini sebaiknya karyawan dari supplier melakukan vaksinasi Covid19 untuk merangsang sistem kekebalan tubuh, vaksin yang disuntikkan akan merangsang antibodi untuk belajar dan mengenal virus yang telah dilemahkan tersebut maka dengan demikian tubuh akan mengenal virus dan mengurangi risiko terpapar Covid19 sehingga 
supplier dapat menyiapkan barang dan mengatur jadwal pengiriman barang sesuai jadwal yang telah disepakati.

Faktor kelima penyebab keterlambatan pengadaan barang adalah karena barang fabrikasi yaitu sebanyak 10 dari 120 nomor purchase order atau sebesar 8,33\%. Barang fabrikasi yang rangkaian pekerjaannya dari beberapa komponen material yang dirangkai dan dibentuk setahap demi setahap sampai menjadi suatu bentuk yang dapat dipasang menjadi rangkaian alat produksi. Proses fabrikasi tersebut harus melalui beberapa tahap agar proses dapat berurutan dan rapi dalam pengerjaannya. Solusi yang dapat diberikan adalah bagian maintenance dapat melakukan prediksi atau preventif maintenace yang bertujuan mengatur jadwal perbaikan atau penggantian spare part mesin sehingga barang yang dibutuhkan bisa disiapkan sebelum jadwal penggantian dan bisa tersedia pada waktu yang ditentukan.

Faktor keenam yang menjadi penyebab keterlambatan pengadaan barang adalah stock kosong, yaitu sebanyak 9 dari 120 nomor purchase order atau sebesar 7,5\%. Hal ini biasanya terjadi pada barang yang spesifik namun dibutuhkan oleh pelaku industri yang lain. Sebelum diterbitkannya purchase order kepada supplier, perusahaan memastikan ketersediaan barang tersebut dalam stock yang dimiliki oleh supplier yang mana tercantum dalam surat penawaran harga. Apabila spesifikasi barang sudah sesuai dan stock ready, perusahaan dapat langsung menerbitkan purchase order. Namun selama proses purchase order yang mana barang tersebut terjadi fast move, sehingga supplier membutuhkan waktu untuk restock barang tersebut. Sehingga hal ini sering terjadi dan menyebabkan penyerahan barang oleh supplier terlambat dan dapat menghambat proses manufakur perusahaan. Dalam hal ini, bagian pengadaan perlu aktif komunikasi dengan supplier untuk memastikan jadwal penyerahan barang. Selain itu, supplier diharapkan transparansi dalam memberikan informasi stock barang yang sudah diterbitkan dalam bentuk purchase order. Apabila stock barang kosong dan informasi diterima oleh perusahaan, maka bagian pengadaan dapat mencari alternatif supplier lain yang stock barang dalam keadaan ready.

Faktor ketujuh penyebab keterlambatan pengadaan barang adalah progress project yaitu sebanyak 8 dari 120 nomor purchase order atau sebesar 6,67\%. Dalam project melibatkan banyak pihak baik tim maintenance, supplier material, dan tenaga ahli. Contohnya terdapat spare part yang tidak lengkap pada saat akan dilakukan pemasangan. Dalam hal ini solusi yang diberikan adalah sebaiknya perusahaan memastikan jadwal oleh pihak-pihak terkait untuk bisa sesuai jadwal karena apabila salah satu pihak berhalangan maka akan berakibat keterlambatan project.

Faktor kedelapan penyebab keterlambatan pengadaan barang adalah barang spesifik yaitu sebanyak 3 dari 120 nomor purchase order atau sebesar 2,50\%. Barang spesifik merupakan barang yang mempunyai karakteristik produk yang unik dan berbeda daripada umumnya. Dalam hal ini sebaiknya planner mengidentifikasi barangbarang yang spesifik kemudian menentukan minimum stock dan mencari supplier pendamping yang dapat memenuhi barang tersebut agar tidak terjadi keterlambatan dalam pengiriman barang. 
Analisis Penyebab yang Mempengaruhi Terjadinya Keterlambatan Pengadaan Barang Pada PT. Petrojaya Boral Plasterboard Gresik

Faktor kesembilan penyebab keterlambatan pengadaan barang adalah tukar barang karena tidak sesuai yaitu sebanyak 2 dari 120 nomor purchase order atau sebesar $1,67 \%$. Perusahaan menukar barang karena barang yang dikirimkan oleh supplier tidak sesuai dengan barang yang diminta oleh perusahaan. Solusi yang dapat diberikan yaitu bagian pengadaan sebaiknya mengingatkan kepada supplier sebelum mengirimkan barang hendaknya memastikan terlebih dahulu bahwa barang yang akan dikirimkan sudah sesuai permintaan perusahaan.

Faktor terakhir penyebab keterlambatan pengadaan barang adalah menunggu design yaitu sebanyak 1 dari 120 nomor purchase order atau sebesar $0,83 \%$. Spare part yang perlu diperbaiki membutuhkan design yang sesuai dibutuhkan oleh perusahaan (Prasetyo, 2013). Dalam hal ini solusi yang diberikan adalah sebaiknya planner mengumpulkan semua data design pada satu folder sehingga pada saat design tersebut dibutuhkan planner dapat melihat pada folder tersebut tanpa perlu mencarinya terlalu lama.

\section{Kesimpulan}

Kelancaran proses manufaktur dalam suatu perusahaan sangat dipengaruhi oleh proses pengadaan barang dalam suatu perusahaan. Sehingga bagian pengadaan perlu membuat strategi yang baik dalam proses pengadaan tersebut. Bagian pengadaan juga perlu memperhatikan lead time agar dalam prosesnya tidak terjadi keterlambatan dalam proses penyerahan barang oleh supplier. Berdasarkan hasil penelitian yang dilakukan di PT. Petrojaya Boral Plasterboard Gresik ditemukan terjadinya keterlambatan proses pengadaan akibat supplier terlambat dalam penyerahan barang. Banyak faktor yang menyebabkan hal tersebut terjadi, yang mana menurut analisis terdapat 10 faktor. Diantaranya faktor dengan skala frekuensi paling besar adalah karena barang dengan status inden. Kebutuhan barang inden memang tidak dapat dihindari terutama dalam proses manufaktur, namun pentingnya bagian pengadaan mengatasi masalah tersebut yaitu dengan memperhatikan saldo minimum barang agar barang dapat terpenuhi tanpa terjadi kehabisan stock.

Keterlambatan pengiriman barang dari supplier ke perusahaan bukan hanya kesalahan dari pihak supplier saja, namun ada hal lain yang iku mempengaruhi yaitu situasi pandemi akibat Covid-19 yang diberlakukannya Pemberlakuan Pembatasan Kegiatan Masyarakat (PPKM) (Yanuar \& Tyas, 2015). Bagian pengadaan perlu memastikan kepada bagian planner untuk dapat membuat forecast rencana kebutuhan beberapa periode kedepan agar bagian pengadaan dapat menjaga stock persediaan barang sehingga meminimalisir terjadinya keterlambatan pengadaan barang. 
In'amy Fawwaz, Abdurrahman Faris Indriya Himawan

\section{Bibliografi}

Alif, Alif Imanuddin. (2020). Penerapan Metode Analytical Hierarchy Process Terhadap Keputusan Pemilihan Supplier Dalam Pengadaan Material Canvas Menggunakan Software Expert Choice. Jurnal Indonesia Sosial Teknologi, 1(2), 73-81.

Aryadi, Heri, \& Wahyuni, Wahyuni. (2019). Tinjauan Prosedur Pembelian Barang di Bagian Purchasing pada PT. Duraconindo Pratama Jakarta. Jurnal Akuntansi Dan Manajemen, 16(02), 225-236.

David, Fred R. (2011). Strategic Manajemen Strategis Konsep. Edisi.

Fuad, Muhammad. (2006). Pengantar bisnis. Gramedia Pustaka Utama.

Indriani, Imaya, \& Slamet, Achmad. (2015). Analisis Pengendalian Persediaan Bahan Baku Dengan Metode Economic Order Quantity pada PT. Enggal Subur Kertas. Management Analysis Journal, 4(2).

Jusriadi, Edi, \& Ario, Ario. (2020). Evaluasi Sistem Akuntansi Manajemen terhadap Kelancaran Proses Produksi pada PT. Semen Bosowa. Invoice, 2(1), 21-37.

Kamaluddin, Ir Hj Apiaty, \& Patta Rapanna, S. E. (2017). Administrasi Bisnis (Vol. 1). Sah Media.

Prasetyo, Wiranto Dwi. (2013). Analisis Penyebab Yang Mempengaruhi Terjadinya Keterlambatan Pengadaan Barang Pada Departemen Pengadaan Barang Dan Bahan Baku Di Pt. Pupuk Kaltim. Jurnal Ilmiah Mahasiswa FEB, 2(2).

Prayunantyo, Bintan, \& Supriono, Supriono. (2017). Analisis Strategi Pembelian dalam Upaya Pengadaan Part Material Import (Studi pada PT. Indonesia Nippon Seiki). Jurnal Administrasi Bisnis, 50(3), 118-127.

Probowati, Anna. (2011). Strategi pemilihan supplier dalam Supply Chain Management pada bisnis ritel. Segmen Jurnal Manajemen Dan Bisnis, 7(1).

Pujawan, I. Nyoman. (2017). Mahendrawathi. Supply Chain Management, 3.

Siahaya, Willem. (2013). Manajemen Pengadaan. Bandung: Alfabeta.

Sihotang, Kasdin. (2019). Aplikasi kasus Siklus Transaksi Bisnis: Suatu Pendekatan Pengembangan Sistem Informasi Akuntansi. Penerbit Unika Atma Jaya Jakarta.

Sugiyono. (2017). Metode Penelitian Kuantitatif, Kualitatif, dan R\&D. Bandung.

Sutarman, H., \& Atif, Nurul Falah. (2017). Dasar-Dasar Manajemen Logistik. 